Research

\title{
The Dynamic of Insect Population Succession in Bird Poisoned by Pyrethroid Insecticides
}

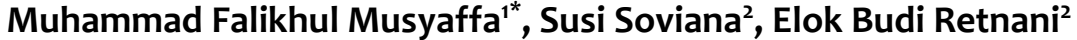 \\ 'Entomology Laboratory, Faculty of Veterinary Medicine, IPB University, Bogor, Indonesia \\ ${ }^{2}$ Department of Animal Disease and Veterinary Public Health, Faculty of Veterinary Medicine, \\ IPB University, Bogor, Indonesia \\ *Corresponding author: mfalikhul@gmail.com \\ Submitted April 2, 2021 Accepted May 15, 2021
}

\begin{abstract}
Insecticide poisoning is one of the causes of death in wild birds. One of the insecticides that are often used is a pyrethroid. This study aims to determine the succession of insects in birds intoxicated by pyrethroid pesticide. This research was conducted in Dramaga campus, IPB University, Bogor, Indonesia. One quail (Coturnix coturnix japonica) was used as a control which was killed by manual neck dislocation, and one bird was treated orally treated with acute dose pyrethroid pesticide. Cadavers are placed in insect traps until they reach the skeletal stage of decomposition. Insects that enter the trap are collected every 6 hours for 24 hours, from the first day until the whole process of decomposition of the carrion reaches the skeletal stage. Then the insects are identified and counted. The results showed that the cadaver decomposition process in the treatment group took longer than the control group. In the control group, insects arrived for approximately 138 hours after the cadaver was placed, while the treatment group took approximately 324 hours. The types of insects in these two groups are relatively the same, namely flies (Order Diptera: Calliphoridae, Muscidae), cockroaches (Order Dictyoptera: Blattidae and Blaberidae) and Sarcophagidae), beetles (Order Coleoptera: Scarabidae), ants (Order Hymenoptera: Formicidae), earwigs (Order Dermaptera: Anisolabididae). Chrysomya megachepala was the dominant insect over the others and was always present from the early stages to post-decay in control and pyrethroid treatment.
\end{abstract}

Keywords: succession, insect, birds, pyrethroid, poisoning

\begin{abstract}
ABSTRAK
Keracunan insektisida merupakan salah satu penyebab kematian burung liar. Salah satu insektisida yang sering digunakan adalah piretroid. Penelitian ini bertujuan untuk mengetahui suksesi serangga pada burung yang mengalami keracunan pestisida piretroid. Penelitian ini dilakukan di kampus Dramaga, IPB University, Bogor, Indonesia. Satu ekor burung puyuh (Coturnix coturnix japonica) digunakan sebagai kontrol yang dimatikan dengan cara dislokasi leher secara manual, dan satu ekor yang diberi perlakuan pestisida piretroid dosis akut secara oral. Bangkai ditempatkan dalam perangkap serangga hingga mencapai tahap tulang pada dekomposisi. Serangga yang masuk perangkap dikoleksi setiap 6 jam selama 24 jam, mulai hari pertama hingga seluruh proses pembusukan bangkai mencapai tahap kerangka. Hasil penelitian menunjukkan bahwa proses dekomposisi karkas pada perlakuan piretroid membutuhkan waktu yang lebih lama dibandingkan dengan kontrol. Pada kontrol, serangga datang kurang lebih 138 jam setelah bangkai ditempatkan, sedangkan pada perlakuan piretroid memakan waktu kurang lebih 324 jam. Jenis-jenis serangga yang terdapat pada dua kelompok ini relatif sama, yaitu lalat (Ordo Diptera: Calliphoridae, Muscidae), kecoa (Ordeo Dictyoptera: Blattidae dan Blaberidae) dan Sarcophagidae), kumbang (Ordo Coleoptera: Scarabidae), semut (Ordo Hymenoptera) : Formicidae), cocopet (Ordo Dermaptera: Anisolabididae). Chrysomya megachepala menjadi serangga yang mendominasi daripada yang lain dan selalu hadir mulai tahap awal sampai pasca pembusukan pada kontrol maupun perlakuan piretroid.
\end{abstract}

Kata kunci: suksesi, serangga, burung, piretroid, keracunan 


\section{INTRODUCTION}

Insects are the most dominant living things in nature. Its ability to adapt to extraordinary environments is a factor that supports insect dominance (Kristanto et al. 2009). One of the adaptations of insects is as a decomposer. Decomposer insects perform decomposition of dead organisms that are broken down into parts or basic elements that compose them, and in the final process the remains of animals or plants will gradually disintegrate until their structure cannot be recognized, and complex organic molecules will be fragmented (Capinera 2008). Decomposer insects are also useful for revealing cases of death because they can be an indicator in estimating the post mortem interval (PMI) by observing and studying the activity patterns of insects found in carcasses (Miller and Virginia 2002; Benecke 2004; Byrd and Castner 2010; Leccese 2010; Joseph et al. 2011; Wells et al. 2001).

Decomposing of a carcass by insects can be influenced by several factors, including mortality from insecticide poisoning because decomposer insects are attracted to the carcass due to biological, chemical and physical changes. This supports the formation of new ecosystems followed by a succession pattern of various insect species. The insects that come will interact with each other either neutrally, competition or predation, all of which will affect the process of carcass decomposition. Also, various insect species have sequential arrival patterns according to the decomposition stage (Wolff et al. 2001; Archer 2003; Voss et al. 2008; Tuzun et al. 2010), this is known as insect succession. Cadavers that contain insecticides or are in areas surrounded by insecticides will experience a rejection reaction from insects to carry out the decomposition process (Marchenko 1988; Charabidze et al. 2009). It also slows down the decomposition process because each type of insect has a different response and resistance to insecticides (Campobasso et al. 2001).

Kim et al. (2016) reported that wild bird deaths occurred in Korea from 2010 to 2013 due to poisoning from various insecticides due to eating agricultural products or insect pests contaminated with insecticides. The same was reported by McLeod and Saunders (2013) in Australia. Eventually, the cadaver of the wild birds will be decomposed by certain decomposer insects with different succession patterns depending on the type of insecticide that contaminates the cadaver.

This study aims to determine the potential of insects' potential for determining mortality in birds with insecticide poisoning by identifying specific types and patterns of insecticide decomposer succession.

\section{MATERIAL AND METHODS}

\section{Time and Location}

This research was conducted in August - November 2020 in Dramaga District, Bogor Regency. Sampling was carried out at the Arboretum Landscape, IPB University. The preservation and insect identification stages were carried out at the Medical Entomology Laboratory, Faculty of Veterinary Medicine, IPB University.

\section{Animal Model}

The animal model used was two quails (Coturnix coturnix japonica) weighing 100 gr. Each quail was used as control and treatment. Control quail was killed using the cervical dislocation technique. In contrast, the treated quails were given an acute oral dose of pyrethroid insecticide based on OECD 223 guidelines: Acute Oral Toxicity Up and Down Procedure (WHO 2004). The use of experimental animals in this study has received permission from the Animal Welfare Ethics Commission of the Animal Hospital of FKH IPB University No: 006 / KEH / SKE / III / 2020.

\section{Placement of cadaver}

Quail cadavers were each placed in a pyramid trap measuring $30 \times 30 \times 40 \mathrm{~cm}$ at $06.00 \mathrm{WIB}$ (Figure 1). Each side of the trap is walled with gauze, which allows the smell of quail cadaver to be detected by decomposer insects. The bottom of the trap is given a gap about $1 \mathrm{~cm}$ high so that decomposer insects can enter the trap.

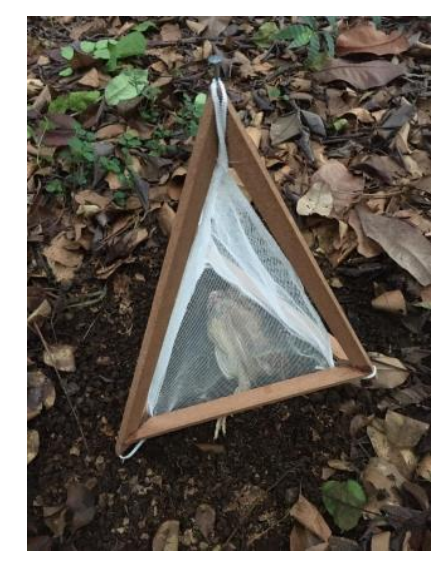

Figure 1 Traps 
104 | Musyaffa et al.

\section{Collection and observation of insect activity}

The insect observation activity begins with a collection of insects which is carried out every six hours. The collection of flying decomposers was carried out using traps and non-flying insects were collected manually with cotton soaked in $70 \%$ alcohol. The insects collected are then processed as dry specimens using the pinning method and stored in a specimen box. The number of insects collected from the collection is also calculated to determine the various types of insects and their activity patterns at each observation time.

\section{Insect identification}

Insect identification was carried out using identification keys AHA (2020), Amendt et al. (2010), Borror et al. (1993) and by matching existing specimens in the Laboratory of Medical Entomology, Faculty of Veterinary Medicine, IPB University.

\section{Measurement of the decomposition stage and other decomposition factors}

Measurements of the decomposition stage and the factors affecting the decomposition of cadaver were carried out simultaneously and frequently as the insect collection activities. Measurement of a cadaver's decomposition stage is carried out by observing changes in the morphology/anatomy of a bird cadaver in each observation. In contrast, the factors that influence the cadaver's decomposition have measured the temperature of the cadaver, the temperature and humidity of the environment around the cadaver (Smith 1986).

\section{Data analysis}

Data on the decomposition stage characteristics, types and numbers of decomposer insects, and arrival time of decomposer insects are presented in tables and graphs. Analysis of insect species diversity data by calculating relative abundance (RA) as well as the Shannon-Wiener species diversity index $\left(\mathrm{H}^{\prime}\right)$ (Odum 1993). The diversity index criteria are high if $\mathrm{H}>3$ is moderate $1 \leq \mathrm{H} \leq 3$, and low is $\mathrm{H}<1$ (Michael 1995).

\section{RESULTS AND DISCUSSION}

\section{Various types of insect}

The total number of insects found in both treatments amounted to 1488 individuals. There were 766 individual insects in control, 722 individual insects in the pyrethroid treatment. The various types of insects found were flies from the Calliphoridae family (Chrysomya megachepala, C. ruffifacies, C. albiceps, C. marginalis, Chrysomya spp., Lucillia sericata, Lucillia papuensis, and Lucillia spp.), Flies from the Sarcophagidae family (Sarcophaga sp.), flies of the Muscidae family (Musca domestica, Antherogona orientalis, Ophyra sp., and Physiphora sp.), ants of the Formicidae family (Odontoponera transversa, Pheidole sp., Anoplolepis gracilipes, Solenopsis invicta), cockroaches of the Blattidae family (Blattella germanica), cockroaches family Blaberidae (Pygnocelus surinamenensis), beetle family Scarabidae (Scarabaecus sacer), and cocopet family Anisolabididae (Euborellia sp.) (Table 1).

Insects that came to the control treatment and pyrethroid treatment showed that the diversity index value was categorized as moderate, with a value of 2.37 and 2.71 , respectively. The two also showed the same results in terms of the dominant insect, namely C. megachepala.

Observations showed that flies (Calliphoridae, Muscidae, Sarcophagidae) that came to the cadaver had the activity of eating and laying eggs on the cadaver-then followed by other insect members who also eat cadaver and flies larvae, such as beetles (Coleoptera), Hymenoptera (Formicidae), cockroaches (Blattidae, Blaberidae) and cocopets (Anisolabididae). This is supported by the statement from Goff (2016), that after necrophage groups such as flies are present on the cadaver, these insects will attract the second group, namely parasites and predators such as beetles (Silphidae, Staphylinidae, and Histeridae), flies (Stratiomyidae), and parasitic wasps, which will prey on a cadaver or fly larvae and pupae.

\section{Insect activity pattern}

Fluctuations in insects' presence in the cadaver of the control treatment are presented in Figure 2. for 0-12 hours after placing the cadaver in the trap, no insects were found. The presence of insects on the cadaver was found 18 hours after laying the cadaver, including C. megachepala and O. transversa. From the fresh stage to the skeleton stage, the number of insects present was erratic due to the environment's changing temperature and humidity due to rain. This is supported by the statement of Wang et al. (2016), that environmental temperature and humidity significantly affect the pattern of insect activity and cadaver decomposition speed. Besides, the light intensity can also affect insect 
Table 1 Various types of insect

\begin{tabular}{|c|c|c|c|c|}
\hline \multirow{2}{*}{ Ordo } & \multirow{2}{*}{ Family } & \multirow{2}{*}{ Genus/Species } & \multicolumn{2}{|c|}{$\mathrm{RA}(\%)$} \\
\hline & & & Control & Pyrethroid \\
\hline \multirow[t]{13}{*}{ Diptera } & Calliphoridae & Chrysomya megachepala & 31,85 & 21,75 \\
\hline & & Chrysomya albiceps & 1,96 & 2,08 \\
\hline & & Chrysomya spp. & 13,32 & 11,91 \\
\hline & & Chrysomya ruffifacies & 1,57 & 1,66 \\
\hline & & Chrysomya marginalis & 5,35 & 4,43 \\
\hline & & Lucilia spp. & 3,92 & 2,91 \\
\hline & & Lucilia sericata & 1,96 & 3,46 \\
\hline & & Lucilia papuensis & 8,49 & 6,23 \\
\hline & Sarcophagidae & Sarcophaga spp. & 1,83 & 3,88 \\
\hline & Muscidae & Antherigona orientalis & 2,87 & 8,17 \\
\hline & & Physiphora sp. & 7,18 & 7,62 \\
\hline & & Ophyra sp. & 5,35 & 2,08 \\
\hline & & Musca domestica & 6,14 & 3,05 \\
\hline \multirow[t]{4}{*}{ Hymenoptera } & Formicidae & Odontoponera transversa & 2,35 & 5,12 \\
\hline & & Pheidole sp. & 0,52 & 1,25 \\
\hline & & Anoplolepis gracilipes & - & 1,11 \\
\hline & & Solenopsis invicta & - & 1,39 \\
\hline \multirow[t]{2}{*}{ Dictyoptera } & Blattidae & Blattella germanica & 1,17 & 2,49 \\
\hline & Blaberidae & Pygnocelus surinamenensis & - & 1,66 \\
\hline Coleoptera & Scarabidae & Scarabaecus sacer & 2,48 & 4,16 \\
\hline Dermaptera & Anisolabididae & Euborellia sp. & 1,70 & 3,60 \\
\hline
\end{tabular}

activity (Borror et al. 1996). This research also shows that insects only arrive at the fresh stage until the post-decay stage, while the skeleton stage has been confirmed as not coming back.

It was recorded that 19 types of insects were present in the cadaver decomposition process in the control treatment. The emergence of insects from the cadaver's initial laying until the decomposition process ends dominated by members of the Calliphoridae family (C. megachepala, C. albiceps, and Lucilia spp.) and Muscidae family (A. orientalis and Physiphora sp.). Both are always present from the fresh stage to the post-decay stage. The highest number of the five is recorded on the bloated stage until the decay stage, then decreases.

Fluctuations in the presence of insects in the cadaver of pyrethroid treated birds are presented in Figure 3. The arrival of insects on the cadaver was found after 42 hours of being placed. Early insects included C. megachepala, C. albiceps, Sarcophaga spp. and $O$. transversa. The number of insects present, starting from the fresh stage to the post-decay stage, was uncertain, while on the skeleton stage there were no insects found at all. It was recorded that 22 types of insects were present in the decomposition process of pyrethroid cadaver. There are insect species that dominate the present, including members of the Calliphoridae family (C. megachepala, C. albiceps, and Lucilia spp.) and Muscidae family ( $M$. domestica and $A$. orientalis).

The highest presence of insect species from the cadaver's initial placement to the end of the decomposition process is $C$. megachepala. In this treatment, insects are almost always present at the fresh stage until the post-decay stage, after which they are no longer present. Besides that, the insects that were present were also found in many dead conditions. This is because of the insects that come into contact with the insecticides on the cadaver. The condition of the dead insects around the cadaver can be one of the keys in determining PMI in a case of death by insecticide poisoning. 
Many insects in the Calliphoridae family come because they are attracted by the gas produced by the cadaver due to anaerobic bacterial activity in the digestive tract of the cadaver (Matuszewski et al. 2015). Apart from these insects, several other types of insects also come to eat and lay eggs due to blood, tissue degradation, and the odour caused by the gas that comes out on the bloated and decay stages (Badenhosrst and Villet 2018; Gurafi and Mohamed 2015).

\section{Decomoposition stage}

This study's results indicate that the pyrethroid treated bird cadaver's overall decomposition process takes longer than the control. In the pyrethroid treatment, it took a total of about 558 hours, while the control only took about 234 hours. The time difference is thought to be due to the decomposer insects being affected by pyrethroid insecticides in the cadaver's bodies. Pyrethroid insecticides also affect the growth and development of exposed decomposer insect larvae in the cadaver's body. The statement supports this assumption by ASTDR (2003), that pyrethroid insecticides can accumulate in the fat tissue and last a long time in the body because the exposure level is very high or the exposure occurs for a long time. Besides, certain pyrethroid insecticides can last longer on the skin and hair.

Decomposition in both treatments had an ambient temperature value of $25.2-43.8 \mathrm{C}^{\circ}$. The fresh stage of the pyrethroid treatment cadaver took about 54 hours, compared to the control which took about 36 hours at the same ambient temperature range. The bloated stage pyrethroid treatment took about 72 hours, whereas the control only needed about 24 hours. The control only takes about 54 hours compared to the pyrethroid treatment in the decay stage, which takes a longer time, around 126 hours. In the post- decay stage, the pyrethroid treatment

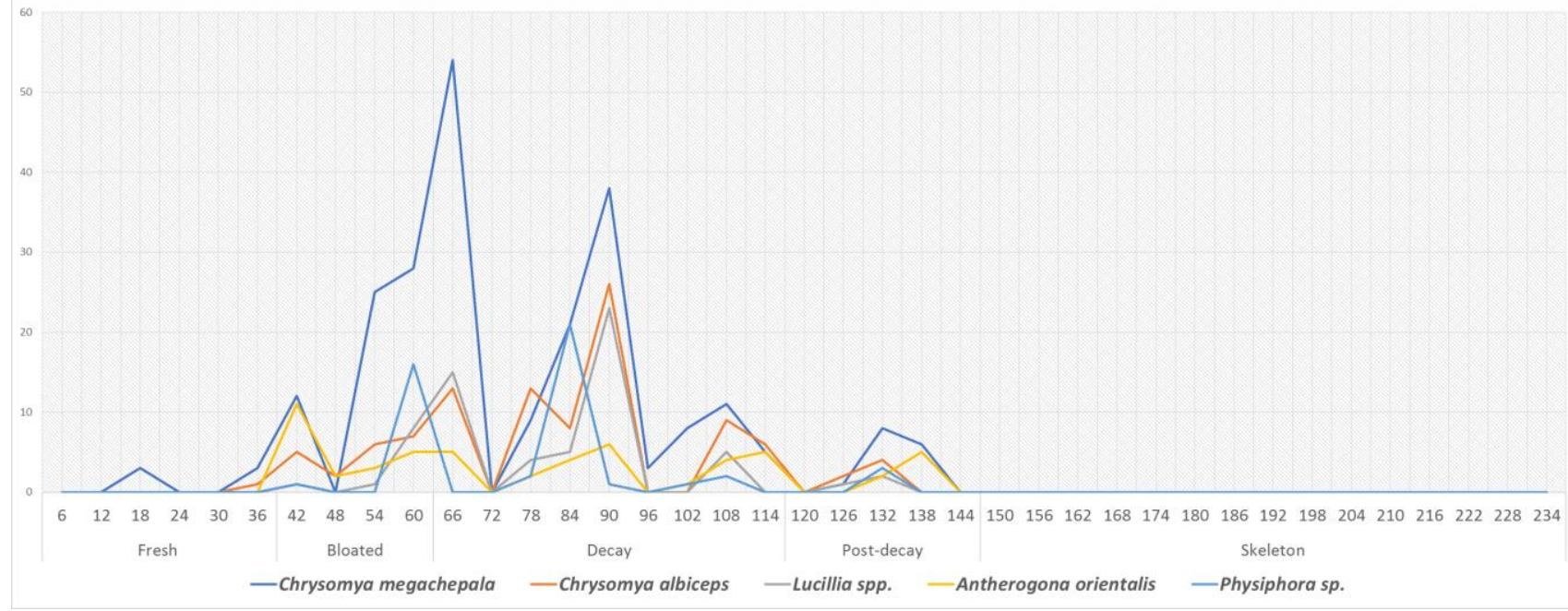

Figure 2 Pattern of insect activity in control-treated bird cadaver

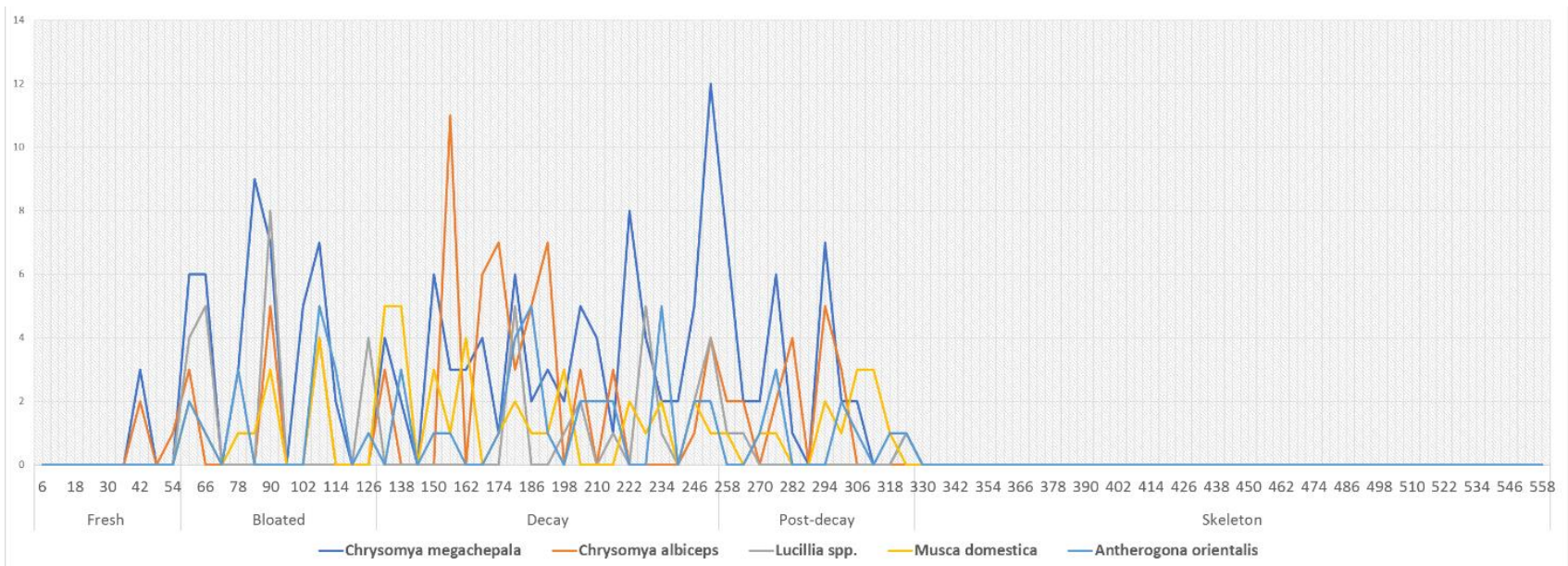

Figure 3 Pattern of insect activity in pyrethroid-treated bird cadaver 
took about 72 hours, while the control took about 24 hours. In the skeleton stage, the pyrethroid treatment took about 234 hours, while the control needed about 96 hours. Smith (1986) explained that the body would experience a decrease in temperature after death occurs. The temperature drop will slow down as it approaches the ambient temperature. Conversely, body temperature will decrease rapidly if the ambient temperature is much lower.

Overall, decomposition of the cadaver of pyrethroid treated birds lasted longer than the control. In the control group, insects arrived for approximately 138 hours after the cadaver was placed, while the treatment group took approximately 324 hours. From the fresh stage to the skeletal stage, it was found that the insect populations that came in the control and pyrethroid treatments were relatively the same, which consisted of families from the order Diptera (Calliphoridae, Muscidae, Sarchopagidae), Coleoptera (Scarabidae), Hymenoptera (Formicidae), Dermaptera (Labiduridae), Dictyoptera (Blattidae, Blaberidae). Both treatments showed C. megachepala to be the most dominant species than the others.

"All authors declare that there are no conflicts of interest".

\section{REFERENCES}

[AHA] Animal Health Australia. 2020. A Manual for the Identification of Screw Worm Fly, Fourth Edition. Canberra ( $A U)$ : Animal Health Australia.

[ASTDR] Agency for Toxic Substances and Disease Registry. 2003. Public Health Statement for Pyrethrins and Pyrethroids. [downloaded on 29 Jan 2021]. Available at: https://www.atsdr.cdc.gov/ ToxProfiles/tp155-c1-b.pdf.

Amendt J, Campobasso CP, Goff ML, Grassberger M. 2010. Current Concept in Forensic Entomology. New York (US): Springer Dordrecth Heidelberg.

Archer MS. 2013. Annual variation in arrival and departure times of carrion insect at carcasses: implications for succession studies in forensic entomology. Aust. J. Zoology. 51 (6): 569-576. DOI: 10.1071/ZO03053

Badenhorst R, Villet MH. 2018. The uses of Chrysomya megacephala (Fabricius, 1794) (Diptera: Calliphoridae) in forensic entomology. Forensic Sci Res. 3(1): 2-15. DOI: 10.1080/20961790.2018.1426136
Benecke M. 2004. A Public Publication Experiment. J Forensic Med Toxicol. 5(1):1-2.

Borror DJ, Triplehorn CA, Johnson NF. 1992. Pengenalan Pelajaran Serangga. Edisi VI. Terjemahan Soetiyono Partosoedjono Yogyakarta (ID): Gajah Mada Press.

Byrd JH and Castner JL. 2010. Forensic Entomology. Florida (US): CRC Press Taylor and Francis Group.

Campobasso CP, Giancarlo DV, Francesco I. 2001. Factors affecting decomposition and Diptera colonization. Forensic Sci Int. 120 (1-2): 18-27. DOI: 10.1016/s0379-0738(01)00411-x

Capinera JL. 2008. Encyclopedia of Entomology. 2nd Edition. Heidelberg (DE): Springer Science \& Business Media.

Charabidze D, Bourel B, Hedouin V, Gosset D. Repellent effect of some household products on fly attraction to cadavers. Forensic Science International. 189 (1-3) 28-33. DOI: 10.1016/j.forsciint. 2009.04.009

Gurafi LMA, Mohamed EAE. 2013. Insects as forensic indicators: analysis of some cases. Sudan $J$ Sci. 5(2): 1-7.

Goff, ML. 2016. Entomology in Encyclopedia of Forensic and Legal Medicine. Amsterdam (NL): Elsevier.

Joseph I, Deepu GM, Pradeesh S, Geetha V. 2011. The use of insects in forensic investigations: An overview on the scope of forensic entomology. J Forensical Dent Sci. 3(2): 89-91. DOI: 10.4103/09751475.92154

Kim S, Mi-Young P, Hyo-Jin K, Jin YS, Kyung YK, DongGyu K, MeeKyung K, Hwan-Goo K, BJS, Sung-Won P. Analysis of Insecticides in Bird Wild in Korea from 2010 to 2013. Bull Environ Contam Toxicol. 96(1): 25-30. DOI: 10.1007/s00128-015-1688-0

Kristanto E, Wangko S, Kalangi S, Mallo J. 2009. Peran Entomologi Forensik dalam Perkiraan Saat Kematian dan Olah Tempat Kejadian Perkara Sisi Medis (Introduksi Entomologi Medik). J Biomedik. 1(1): 41-44.

Leccese A. 2010. Insect as Forensic Indicator : Methodological Aspects. J Med and Toxicol. 5(1): 26-32.

Marchenko MI. 1988. Medico-legal relevance of cadaver entomofauna for the determination of the time since death. Acta Med. Leg. Soc. 38(1): 257-302.

Matuszewski S, Konwerski S, Fritczak K, Szafaowicz M. 2014. Effect of body mass and clothing on decomposition of pig carcasses. Int J Legal Med. 128(6): 1039-1048. DOI: 10.1007/s00414-014-0965-5

Mcleod L and Saunders G. 2013. Pesticides used in the Management of Vertebrate Pests in Australia: A Review. [downloaded on 29 Jan 2021]. Available at:ttps://www.dpi.nsw.gov.au/_data/assets/pdf 
_file/0007/486187/Pesticides-used-in-the management-of-vertebrate-pests-in-australia-a-review.pdf

Michael P. 1995. Metode Ekologi untuk Penyelidikan Lapangan dan Laboratorium. Terjemahan Yanti R. Koester. Jakarta (ID): UI-Press.

Miller JS, Virginia LN. 2002. Forensic Entomology for the Laboratory-Based Biology Classroom. The American Biology Teacher. 64(2): 136-141. DOI: 10.1662/0002-7685(2002)064[0136:FEFTLB] 2.0.CO;2

Odum EP. 1993. Dasar-Dasar Ekologi. Edisi Ke 3. Translated by Tjahjono Samingan. Yogyakarta (ID): Gadjah Mada University Press.

Tuzun A, Dabiri F, Yuksel S. 2010. Preliminary Study and Identification of Insects' Species of Forensic Importance in Urmia, Iran. J African Biotechnol. 9(24): 3649-3658. DOI: https://doi.org/10.5897/ AJB 2010.000-3230
Voss SC, Shari LF, Ian RD. 2008. Decomposition and Insect Succession on Cadavers Inside a Vehicle Environment. University of Western Australia. Forensic Sci Med Pathol. 4: 22-32. DOI: https://doi.org/10.1007/s12024-007-0028-z

Wang Y, Li LL, Wang JF, Wang M, Yang LJ, Tao LY, Zhang YN, Hou YD, Chu J, Hou ZL. 2016. Development of the green bottle fly Lucilia illustris at constant temperatures. Forensic Sci Int. 267:136-144. DOI: https://doi.org/10.1016/j.forsciint. 2016.07.019

Wells JD, LaMotte LR. 2001. Estimating the postmortem interval in Forensic Entomology. The Utility of Arthropods in Legal Investigations. Boca Raton (US): CRC Press.

Wolff M, Uribe A, Ortiz A, Duque P. 2001. A Preliminary Study of Forensic Entomology in Medellin, Colombia. Forensic Sci Int. 120(1-2): 53-59. DOI: 10.1016/S0379-0738(01)00422-4 